\title{
The effect of soluble E-selectin on tumor progression and metastasis
}

\author{
Shin-Ae Kang ${ }^{1}$, Celine A. Blache², Sandra Bajana', Nafis Hasan², Mohamed Kamal', Yoshihiro Morita', Vineet Gupta', \\ Bilegtsaikhan Tsolmon ${ }^{1}$, K. Stephen Suh ${ }^{3}$, David G. Gorenstein ${ }^{4}$, Wajeeha Razaq ${ }^{5}$, Hallgeir Rui ${ }^{6}$ and Takemi Tanaka ${ }^{1,7^{*}}$
}

\begin{abstract}
Background: Distant metastasis resulting from vascular dissemination of cancer cells is the primary cause of mortality from breast cancer. We have previously reported that E-selectin expression on the endothelial cell surface mediates shear-resistant adhesion and migration of circulating cancer cells via interaction with CD44. As a result of shedding, soluble E-selectin (sE-selectin) from the activated endothelium is present in the serum. In this study, we aimed to understand the role of sE-selectin in tumor progression and metastasis.

Methods: We investigated the effect of sE-selectin on shear-resistant adhesion and migration of metastatic breast cancer cells and leukocytes in vitro and in vivo.

Results: We found that sE-selectin promoted migration and shear-resistant adhesion of CD44 ${ }^{+/ \text {high }}$ breast cancer cell lines (MDA-MB-231 and MDA-MB-468) to non-activated human microvessel endothelial cells (ES-HMVECs), but not of CD44-1ow breast cancer cell lines (MCF-7 and T-47D). This endothelial E-selectin independent, sE-selectin-mediated shear-resistant adhesion was also observed in a leukocyte cell line (HL-60) as well as human peripheral blood mononuclear cells (PBMCs). Additionally, the incubation of MDA-MB-231 cells with sE-selectin triggered FAK phosphorylation and shear-resistant adhesion of SE-selectin-treated cells resulted in increased endothelial permeabilization. However, CD44 knockdown in MDA-MB-231 and HL-60 cells resulted in a significant reduction of sE-selectin-mediated shear-resistant adhesion to non-activated HMVECs, suggesting the involvement of CD44/FAK. Moreover, functional blockade of ICAM-1 in non-activated HMVECs resulted in a marked reduction of sE-selectin-mediated shear-resistant adhesion. Finally, the pre-incubation of $\mathrm{CD}_{4} 4^{+} 4 \mathrm{~T} 1$ murine breast cancer cells with sE-selectin augmented infiltration into the lung in E-selectin $\mathrm{K} / \mathrm{O}$ mice and infusion of human PBMCs pre-incubated with sE-selectin stimulated MDA-MB-231 xenografted breast tumor growth in NSG mice.
\end{abstract}

Conclusions: Our data suggest that circulating sE-selectin stimulates a broad range of circulating cells via CD44 and mediates pleiotropic effects that promote migration and shear-resistant adhesion in an endothelial E-selectin independent fashion, in turn accelerating tissue infiltration of leukocytes and cancer cells.

Keyword: sE-selectin, E-selectin, Shear-resistant adhesion, CD44, Hematogenous metastasis

\section{Background}

Tissue infiltration of circulating cells is critical for multiple aspects of tumor progression and metastasis. First, extravasation of circulating leukocytes into the primary tumor aids in the development of a tumor

\footnotetext{
* Correspondence: takemi-tanaka@ouhsc.edu

'Department of Pathology, University of Oklahoma Health Sciences Center, 975 NE, 10th, Oklahoma City, OK 73104, USA

${ }^{7}$ Stephenson Cancer Center at the University of Oklahoma Health Sciences Center, 975 NE 10th, Oklahoma City, OK 73104, USA

Full list of author information is available at the end of the article
}

stroma that provides a fertile environment for cancer cells to survive and grow. Second, extravasation of circulating tumor cells into the tissue parenchyma of distant organs gives rise to metastasis. Despite the recognized importance of tissue infiltration in tumor progression and metastasis as well as pathologic alterations in the global serum protein profiles of cancer patients, it is uncertain whether circulating factors in the vascular space extrinsically stimulate circulating cells to infiltrate tissues. During tissue infiltration, inflamed vascular endothelium, characterized by expression of E-selectin and CAMs, 
functions as a gateway to tissue parenchyma. Tissue infiltration by circulating cells is governed by a multi-step adhesion cascade, mediated by sequential interactions and crosstalk between adhesion molecules expressed on the endothelial cell surface and their counter-receptor ligands expressed on circulating cells [1-4]. A robust interaction is required for this attachment to resist swift blood flow. Weak interaction prevents effective attachment of the circulating cells to the endothelial surface. The initial adhesion of circulating cells subsequently leads to firm attachment that opens the endothelial junction enabling transendothelial migration into tissue parenchyma toward cytokine or chemokine stimuli $[5,6]$.

Adhesion molecules, such as selectins, ICAM, and VCAM, expressed on the endothelial surface in response to inflammatory stimuli are the primary mediators of tissue infiltration [7, 8]. E-selectin (CD62E, ELAM-1, or LECAM-2) is expressed exclusively on the luminal surfaces of inflamed vasculature [9] and mediates rolling and vascular adhesion through interaction with carbohydrate ligands [10, 11]. A variety of ligands for E-selectin have been identified in different types of cells; these include CD44 (HCELL) [12-14], Mac-2 binding protein [15], Muc-1 [16], death receptor-3 [17], and ESL-1 [18]. The expression of E-selectin is temporally and spatially limited. E-selectin is shed into circulation (soluble Eselectin: sE-selectin) or internalized rapidly after activation. An abundance of sE-selectin in the serum is indicative of inflammation [19-23], and circulating sE-selectin levels are consistently high among individuals with chronic inflammation compared to their healthy counterparts [24]. Similarly, elevated serum levels of sE-selectin were reported and positively associated with tumor grade, tumor stage, and metastases in breast cancer [3, 25]. Despite the positive associations between sE-selectin and breast cancer progression and metastasis, it is unclear whether sE-selectin plays any functional role in tumor progression. In the present study, we demonstrate that sE-selectin functions as a signaling molecule in circulation with the ability to 1 ) enhance shear-resistant adhesion and migration of CD44 $4^{+/ h i g h}$ breast cancer cells (BCs) and leukocytes in an endothelial E-selectin independent fashion, 2) activate focal adhesion kinase (FAK), 3) promote homing of CD $44^{+/ \text {high }} \mathrm{BCs}$ to the lung, and 4) stimulate tumor growth and intratumoral infiltration of PBMCs. These findings identify a possible extrinsic mechanism by which an inflammation-associated factor (i.e., sE-selectin) present in circulation pleiotropically stimulates circulating tumor cells toward tumor progression and metastasis.

\section{Methods}

\section{Cell lines and culture conditions}

Human breast cancer cell lines MDA-MB-231, MDAMB-468, T-47D, and MCF-7, human leukocyte cell line
HL-60, and murine breast cancer cell line 4 T1 were purchased from ATCC (Rockville, MD). MDA-MB-231, MDA-MB-468, MCF-7, and 4 T1 cells were cultured in Dulbecco's Modified Eagle Medium (DMEM; Cellgro) supplemented with $10 \%$ fetal bovine serum (FBS), $2 \mathrm{mM}$ GlutaMAX, and 100U/ml Penicillin-Streptomycin (Life Technology, Grand Island, NY). T-47D and human PBMCs cells were cultured in RPMI-1640 supplemented with $10 \%$ FBS, 2 mM GlutaMAX, and 100U/ml PenicillinStreptomycin. HL-60 cells were cultured in IMDM supplemented with $20 \%$ FBS, 100U/ml Penicillin-Streptomycin, and Insulin-Transferrin-Selenium $(100 \mathrm{mg} / \mathrm{L}$ Insulin; $5.5 \mathrm{mg} / \mathrm{L}$ Transferrin; $6.7 \mu \mathrm{g} / \mathrm{L}$ Selenium; Corning, Manassas, VA). CD44 knockdown clones were generated by transducing the cells with CD44 shRNA lentivirus or control shRNA (Santa Cruz, CA), followed by selection with puromycin. 4 T1-Luc was generated by transducing $4 \mathrm{~T} 1$ cells with luciferase lentivirus (Capital Biosciences) followed by selection using $6 \mu \mathrm{g} /$ $\mathrm{ml}$ puromycin (InvivoGen). Human Microvascular Endothelial cells (HMVECs) and E-selectin-expressing Tet-on inducible HMVECs [26] were cultured in endothelial basal medium-2 (EBM-2; Lonza) supplemented with $2 \%$ tetapproved FBS and an EGM SingleQuot Kit containing epidermal growth factor (EGF), hydrocortisone, gentamicin, and amphotericin B (GA-1000; Lonza). All cells were cultured in $5 \% \mathrm{CO}_{2}$ humid chambers at $37{ }^{\circ} \mathrm{C}$.

\section{Reagents and antibodies}

Recombinant human sE-selectin was purchased from R\&D Systems. Monoclonal antibodies for pFAK and total FAK were purchased from Cell Signaling. Blocking antibodies for ICAM and VCAM were purchased from Santa Cruz and Biolegend, respectively. FAK inhibitor II was purchased from Calbiochem.

\section{In vitro cell adhesion assay}

HMVECs were grown to confluence in the flow chamber ( $\mu$-Slide I 0.4 Luer for cancer cells and 0.2 for leukocytes; Ibidi, Madison, WI) coated with collagen I and fibronectin. The cells $\left(10^{5}\right.$ cells $\left./ \mathrm{ml}\right)$ were pre-incubated with 100 $\mathrm{nM}$ sE-selectin for $10 \mathrm{~min}$ and perfused over a $5 \mathrm{~min}$ period into the flow chamber in $1 \%$ FBS containing DMEM medium at a shear stress rate of $1 \mathrm{dyn} / \mathrm{cm}^{2}$. Unbound cells were washed off with DMEM containing $1 \%$ FBS. Using a light microscope at a final magnification of $100 \times$, the number of cells that adhered to endothelial cells was determined by counting cells in at least five random fields. The data are expressed as the mean of triplicate experiments.

\section{In vitro permeability assay}

HMVECs were grown to confluence on the top-facing side of a collagen-coated 0.4- $\mu \mathrm{m}$-pore transwell chamber 
(Corning). MDA-MB-231 cells were pre-incubated with $100 \mathrm{nM}$ sE-selectin for $10 \mathrm{~min}$ at $37{ }^{\circ} \mathrm{C}$. MDA-MB-231 cells $\left(2 \times 10^{3}\right.$ cells $)$ suspended in EBM-2 media and 2000-kDa FITC-dextran (final concentration of $1 \mathrm{mg} / \mathrm{ml}$, Sigma-Aldrich) were seeded into the upper chamber, and $600 \mu \mathrm{l}$ EBM-2 media was added to lower chamber. Then, at the indicated time points, $50-\mu \mathrm{l}$ aliquots were removed from the lower chamber and the fluorescence was measured at $485 / 530 \mathrm{~nm}$ with a CLARIOstar fluorimeter (BMG Labtech).

\section{Cell migration assay}

Transwell migration assays were performed using a $12.0-\mu \mathrm{m}$ or $5.0-\mu \mathrm{m}$ pore transwell chamber (Becton Dickinson). Cancer cells $\left(2.5 \times 10^{4}\right.$ cells $)$ or leukocytes $\left(1.0 \times 10^{5}\right.$ cells $)$ suspended in serum-free media were applied to the upper chamber and $100 \mathrm{nM}$ sE-selectin was added to the lower chamber. After overnight incubation at $37{ }^{\circ} \mathrm{C}$, migrated cells were stained using a HEMA 3 staining kit (Pierce) and counted under a light microscope.

\section{Anoikis assay}

Anoikis resistance was measured using ultra-low attachment plates (Corning). Cancer cells $\left(10^{4}\right.$ cells) were suspended in $1 \%$ FBS containing medium with or without sE-selectin, seeded into 96-well ultra-low attachment plates, and incubated for $72 \mathrm{~h}$. The number of viable and non-viable cells was determined by trypan blue exclusion using a hemocytometer.

\section{Animal models}

All animal housing and handling procedures were in accordance with institutional guidelines at the University of Oklahoma and Thomas Jefferson University. Sixweek-old female Balb/C mice (Jackson Laboratory) or Eselectin knockout mice (C.129S4-Sele $e^{\text {tm1Dmil } / J ; ~ J a c k s o n ~}$ Laboratory) were used for the in vivo cell adhesion assay. Female Balb/C mice or E-selectin knockout mice $(n=3)$ were injected intravenously with 4 T1-luc murine breast cancer cells $\left(3 \times 10^{4}\right.$ in $100 \mu$ l saline $)$ via tail vein. Cancer cells were pre-incubated with $100 \mathrm{nM}$ sEselectin for $10 \mathrm{~min}$ at $37{ }^{\circ} \mathrm{C}$ and washed with PBS to remove sE-selectin carry over before injection. Seven days later, whole lungs were harvested and total RNA was isolated using TRIzol (Life Technologies). Total RNA was reverse transcribed using random hexamer primers and SuperScript ${ }^{\bullet}$ III First-Strand Synthesis Supermix (Life Technologies). qPCR reactions (80 cycle) were performed using TaqMan gene expression master mix (Life Technologies) and the Biorad CFX96 ${ }^{\mathrm{TM}}$ Touch Real-Time PCR Detection System (Biorad). Luciferase and mouse GAPDH primers were used (Life Technologies). Data are presented as delta-Ct relative to an endogenous control, GAPDH. For leukocyte infiltration, MDA-MB231 breast cancer cells were injected into the mammary fat pads of 7-week-old female NOD SCID IL2 receptor gamma chain knockout mice (NSG mice: NOD.CgPrkdc ${ }^{\text {scid }}$ Il2 rg $^{\text {tm1Wjl }} /$ SzJ; Jackson Laboratory, Bar Harbor, $\mathrm{ME})$. Freshly isolated PBMCs from healthy donors were incubated with $10 \mu \mathrm{M}$ Calcein AM (BD bioscience, San Jose, CA) for $30 \mathrm{~min}$. After brief a wash, the Calcein positive PBMCs $\left(2 \times 10^{7}\right)$ were incubated with sE-selectin or saline and slowly infused over $1 \mathrm{~min}$ via tail vein into NSG mice bearing tumors of approximately $300 \mathrm{~mm}^{3}(\mathrm{LxWxH})$. Tumors were harvested to analyze the tissue migration of Calcein-labeled PBMCs. For tumor growth, MDA-MB231-TGL cell line (a kind gift from Dr. Massague, Memorial Sloan-Kettering Cancer Center) was used. Human PBMCs $\left(1 \times 10^{7}\right.$ cells $)$ that were treated with or without sE-selectin were infused via tail vein once a week. Tumor growth was monitored by measuring bioluminescence using IVIS Lumina XR (Caliper, MA) once a week by intraorbital injection of $100 \mu \mathrm{l}$ luciferase $(15 \mu \mathrm{g} / \mathrm{ml})$.

\section{Flow cytometry}

Human CD44-APC (IM7) conjugated antibody (BD Biosciences, CA) was used to select shRNA-infected cells using a Coulter MoFlo cell sorter (Beckman Coulter, Brea, CA). For phenotypic analysis of human PBMCs, tissue was homogenized in cold RPMI, filtered through a $50-\mu \mathrm{m}$ cell strainer, and washed in PBS. The single cell homogenates were incubated with conjugated antibodies (CD4-APCeFluor780, CD45-FITC, CD8PerCPCy5.5, CD14-PE, and CD11c-APC) for $20 \mathrm{~min}$ at $4{ }^{\circ} \mathrm{C}$. Cells were analyzed on an LSRII flow cytometer (BD Bioscience). All data were analyzed with FlowJo software.

\section{Statistical analysis}

All experiments were carried out in triplicate and repeated at least twice independently. The results are presented as Mean $\pm S D$. Comparisons between groups were analyzed using Student's $t$-test. Statistical significance is expressed as ${ }^{*} p<0.05 ;{ }^{* *} p<0.01 ;{ }^{* * *} p<0.001$.

\section{Results}

Soluble E-selectin enhances the shear-resistant adhesion, migration, and anoikis-resistant survival of CD44 $4^{+/ h i g h}$ breast cancer cells

To investigate the effect of sE-selectin on factors pertinent to hematogenous metastasis, we evaluated shear-resistant adhesion, migration, and anoikis-resistant survival using two estrogen receptor (ER)-negative/ CD44 $4^{\text {/high }}$ BCs (MDA-MB-231 and MDA-MB-468), two ER-positive/CD $44^{-/ \text {low }}$ BCs (T-47D and MCF-7), and a line of Tet-on inducible, E-selectin expressing, human microvessel endothelial cells (ES-HMVECs) [26]. A 
confluent monolayer of ES-HMVECs was grown on a collagen/fibronectin-coated parallel flow chamber and was incubated with or without doxycycline for $4 \mathrm{~h}$ to induce the expression of E-selectin. A single cell suspension of BCs was infused into a chamber to recapitulate the shear-resistant adhesion of disseminated/circulating tumor cells to vascular endothelial cells. The adherent $\mathrm{BCs}$ were counted. Incubation of MDA-MB-231 and MDA-MB-468 BCs with sE-selectin increased the shear-resistant adhesion to doxycycline-untreated ESHMVECs (i.e., absence of E-selectin expression on ESHMVECs) 1.9 fold $(p<0.05)$ and 2.0 fold $(p<0.001)$, respectively, compared with adhesion of saline-treated BCs (Fig. 1a). The adhesion of saline-treated MDA-MB231 and MDA-MB-468 BCs to doxycycline-untreated ESHMVECs was negligible, but increased significantly when E-selectin expression was induced in ES-HMVECs by doxycycline (1.8 fold and 2.0 fold, respectively, $p<0.001$ ). The extent of shear-resistant adhesion of sE-selectintreated MDA-MB-231 and MDA-MB-468 BCs to untreated ES-HMVECs was similar to that of saline-treated $\mathrm{BCs}$ to activated ES-HMVECs. In contrast, neither sE-selectin nor endothelial E-selectin enhanced the shear-resistant adhesion of ER+/CD44/low MCF-7 and T47D BCs. These results suggest the involvement of CD44 in sE-selectin-mediated adhesion. Previously, we demonstrated a physical interaction between E-selectin and CD44 isolated from MDA-MB-231 BCs [13]; we then examined the effect of $\mathrm{sE}$-selectin in shRNA-mediated CD44-knockdown MDA-MB-231 BCs. Soluble E-selectininduced shear-resistant adhesion was significantly reduced in two CD44 knockdown clones of MDA-MB-231 BCs (clone 28, 0.29 fold, and clone 36, 0.30 fold, $p<0.001$ ) as compared with saline controls (Fig. 1b).

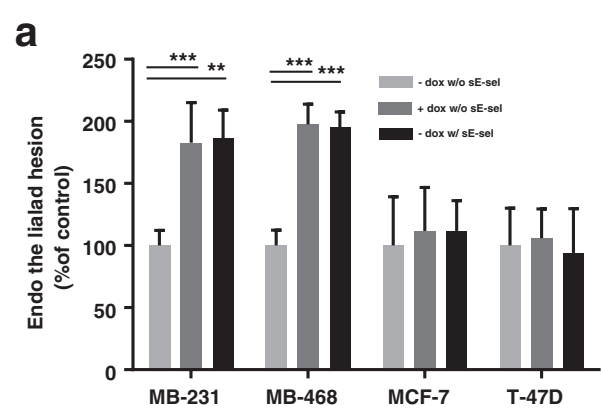

C

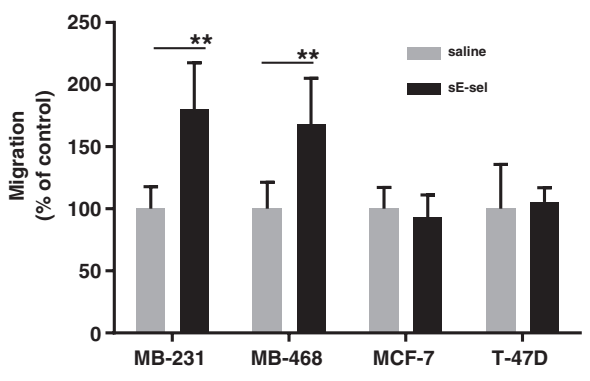

\section{b}
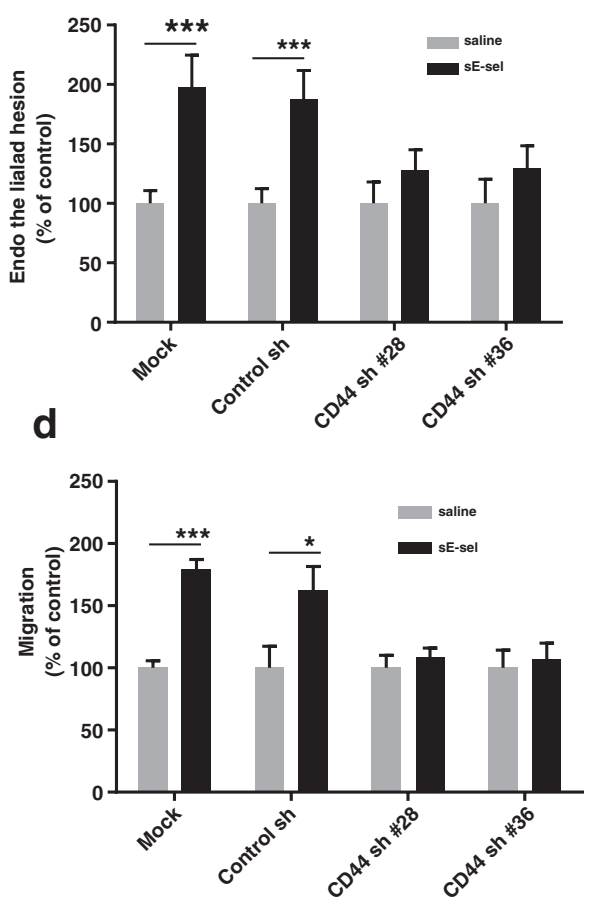

Fig. 1 Soluble E-selectin induces adhesion and migration of CD44 ${ }^{+/ \text {high }}$ BCs: a Effect of sE-selectin on shear resistant adhesion of BCs to endothelial cells. A monolayer of ES-HMVECs was grown on the flow chamber. For endothelial E-selectin expression, ES-HMVECs were incubated with or without doxycycline $(1500 \mathrm{ng} / \mathrm{ml})$ for $4 \mathrm{~h}$. BCs suspensions were incubated with $100 \mathrm{nM}$ sE-selectin for $10 \mathrm{~min}$ and then were infused into flow chambers. The shear-resistant adhesion of $\mathrm{BC}$ cell lines $\left(10^{5} \mathrm{cell} / \mathrm{s} / \mathrm{ml}\right.$ ) was tested at $37^{\circ} \mathrm{C}$ for $5 \mathrm{~min}$ at a rate of $1 \mathrm{dyn} / \mathrm{cm}^{2}$. BCs adhering to endothelial cells were counted under a light microscope. Data were expressed as percentage of control (-Dox/-sEselectin as $100 \%$ \%). b Effect of CD44 knockdown of MDAMB-231 cells on sE-selectin-induced shear-resistant adhesion. Suspensions of MDA-MB-231 cells with CD44 shRNA or control shRNA clone (10 ${ }^{5}$ cells/ $\mathrm{ml}$ ) were treated with sE-selectin or saline and infused into flow chambers after a brief wash. The adhesion of the cells to non-activated ES-HMVECS (-Dox) were counted under a light microscope. Data were expressed as percentage of control (saline treated as $100 \%$ ). c Effect of sE-selectin on the migration of BCs. BCs were seeded into the upper chambers (12- $\mu \mathrm{m}$ pore), soluble E-selectin (100 nM) was added to the lower chambers, and plates were incubated overnight at $37{ }^{\circ} \mathrm{C}$. Migrated cells were stained using an HEMA3 staining kit and were counted under light microscopy. Data were expressed as percentage of control (saline treated as $100 \%$ ). $\mathbf{d}$ Effect of CD44 knockdown of MDA-MB-231 cells on sE-selectin-induced migration. CD44 knockdown clones of MDA-MB-231 cells or control shRNA were added to the upper chambers and migrated cells were counted after overnight incubation at $37^{\circ} \mathrm{C}$. The data represent Mean \pm S.D. ${ }^{*} p<0.05 ; *^{* *} p<0.01 ;{ }^{* * *} p<0.001$ vs. saline, Student's $t$-test. Data were summarized from an experiment conducted in triplicate and repeated twice 
To further examine the role of sE-selectin on migration, we performed a Boyden chamber migration assay. $\mathrm{BCs}$ were added to the upper chamber, while the lower chamber contained culture media, with or without sEselectin. The presence of $\mathrm{sE}$-selectin enhanced migration of CD44 $4^{+/ \text {high }}$ MDA-MB-231 BCs (1.8 fold, $p=0.006$ ) and MDA-MB-468 BCs (1.7 fold, $p=005$ ) (Fig. 1c). However, sE-selectin did not affect the migration of CD $44^{- \text {low }}$ MCF-7 BCs or T-47D BCs (Fig. 1c). Soluble Eselectin-induced migration was also significantly reduced in CD44 knockdown clones of MDA-MB-231 BCs (Fig. 1d). Moreover, sE-selectin increased anoikis resistance in MDA-MB-231 BCs (1.36 fold, $p<0.001)$ and MDA-MB-468 BCs (1.16 fold, $p=0.02$ ), but this effect was not observed in MCF-7 and T-47D BCs (Additional file 1: Figure S1). Therefore, these data suggest that sEselectin specifically enhances anoikis resistant survival, shear resistant adhesion, and migration of $\mathrm{CD} 44^{+/ \text {high }} \mathrm{BCs}$.

\section{Soluble E-selectin enhances shear-resistant adhesion and migration in leukocytes}

To further assess the effect of sE-selectin on circulating cells, leukocyte cell line HL-60 and human peripheral blood mononuclear cells (PBMCs) were used in adhesion and migration assays. Leukocytes $\left(10^{5}\right.$ cells $\left./ \mathrm{ml}\right)$ were infused into a confluent monolayer of parental HMVECs (p-HMVECs) grown on a collagen/fibronectin-coated parallel flow chamber at $1 \mathrm{dyn} / \mathrm{cm}^{2}$ for $5 \mathrm{~min}$ and the adherent cells were counted. Consistent with the data from analysis of $\mathrm{BCs}$, sE-selectin enhanced the shear-resistant adhesion of HL-60 (1.6 fold, $p<0.001$ ) and PBMCs $(2.1$ fold, $p<0.001)$ to non-activated pHMVEC (Fig. 2a). Additionally, sE-selectin enhanced the migration of HL-60 (2.4 fold, $p<0.001$ ), and PBMCs (3.6 fold, $p<0.001$ ) (Fig. 2b). Functional blockade of CD44 in HL-60 using CD44 blocking antibody or a knockdown resulted in reductions of sE-selectin-mediated adhesion to non-activated p-HMVECs $(p<0.001)$. Taken together, these results indicate that $\mathrm{sE}$-selectin may have biological function via CD44 in a broad range of circulating cells including leukocytes and cancer cells.

\section{The shear-resistant adhesion of $\mathrm{sE}$-selectin-treated MDA-MB-231 BCs increases the permeability of non-activated $\mathrm{p}$-HMVECs}

While leaky endothelium is a hallmark of tumorassociated vasculatures, under physiologic conditions, endothelial cells are connected through tight junctions. Adhesion of cancer cells to the activated endothelium is reported to induce endothelial permeability for subsequent transendothelial migration [27, 28]. We next evaluated whether the shear-resistant adhesion of sE-selectin-treated MDA-MB-231 BCs enhanced the permeability of nonactivated p-HMVECs. A single cell suspension of MDA-
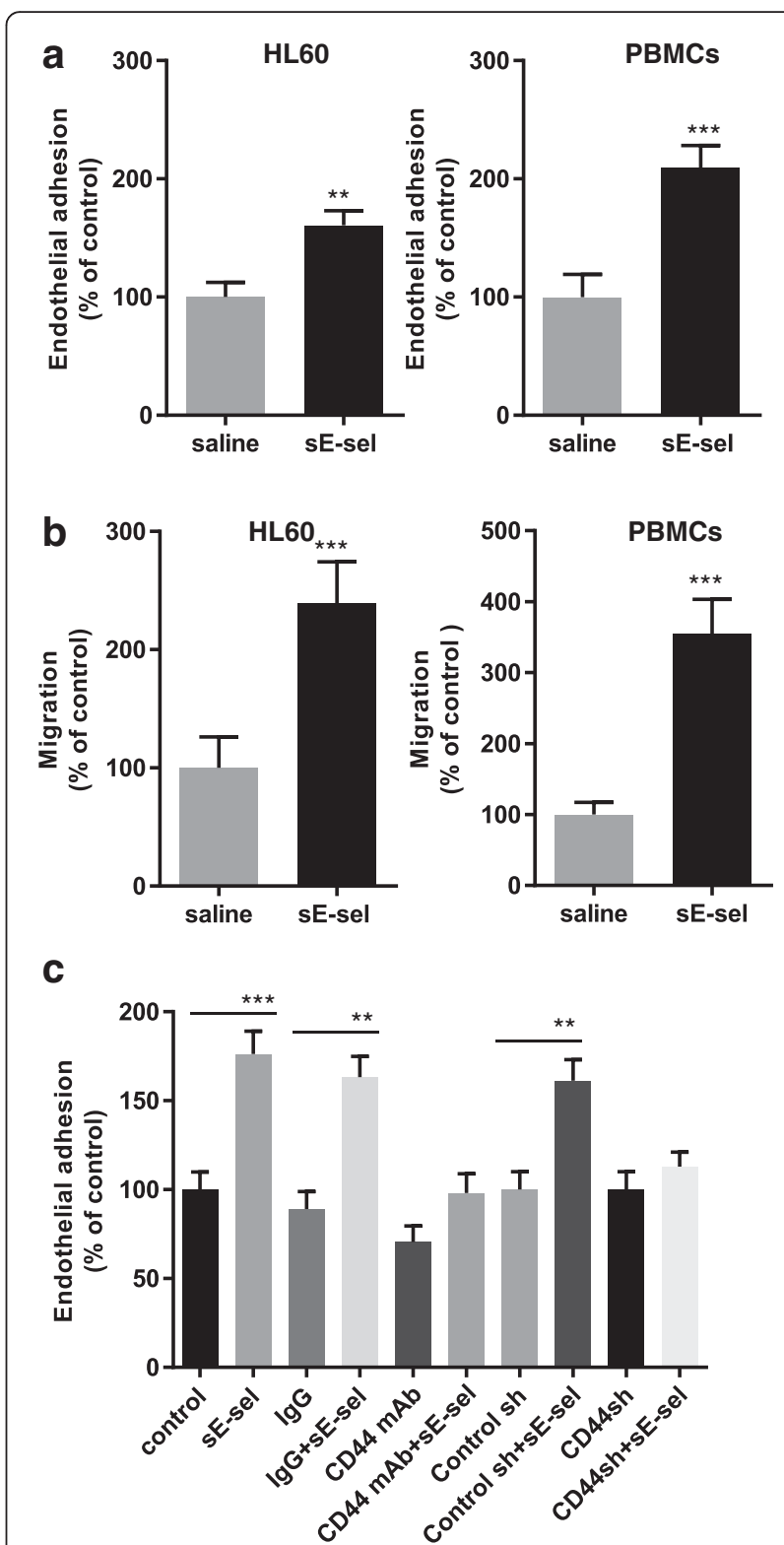

Fig. 2 Soluble E-selectin enhances migration of human leukocytes in vitro. a Effect of sE-selectin on the adhesion of leukocytes to non-activated p-HMVECs. A monolayer of p-HMVECs was grown on the parallel flow chamber. The cells $\left(10^{5}\right.$ cells $\left./ \mathrm{ml}\right)$ were incubated with $100 \mathrm{nM}$ sE-selectin for $30 \mathrm{~min}$ and then infused into the chamber at $37^{\circ} \mathrm{C}$ over a $5 \mathrm{~min}$ period at a shear stress rate of $1 \mathrm{dyn} / \mathrm{cm}^{2}$. Adhesion was expressed as a percent relative to adhesion of salinetreated control cells. b Migration assay was performed using Boyden chamber. HL-60 cells $\left(5 \times 10^{5}\right.$ cells $)$ were seeded in upper chambers ( 5 - $\mu \mathrm{m}$ pores) and $100 \mathrm{nM} \mathrm{sE-selectin} \mathrm{was} \mathrm{supplemented} \mathrm{to} \mathrm{the} \mathrm{lower}$ chambers. The number of migrated cells was counted after $16 \mathrm{~h}$. Migration is expressed as a percent relative to saline-treated control. c Effect of CD44 knockdown of HL-60 on sE-selectin-induced adhesion. The data represent Mean \pm S.D. ${ }^{*} p<0.05 ;{ }^{* *} p<0.01 ;{ }^{* * *} p<0.001$, Student's $t$ test. Data were summarized as \% of respective control from an experiment conducted in triplicate and repeated twice 
MB-231 BCs was pre-incubated with sE-selectin or saline. After a brief spin followed by washing with PBS, the cells were layered onto a confluent monolayer of non-activated p-HMVECs with $2000 \mathrm{kDa}$ FITC-dextran as a fluorescent tracer. Following the addition of sE-selectin-treated MDAMB-231 cells, a steep increase in fluorescent leakage through the HMVEC monolayer was observed (Fig. 3a). In contrast, the adhesion of saline-treated MDA-MB-231 BCs to non-activated p-HMVECs did not have a significant effect on endothelial permeabilization over the course of the $60 \mathrm{~min}$ assay (Fig. 3a). Incubation of p-HMVECs with $\mathrm{sE}$-selectin alone had no effect on endothelial permeability (data not shown). To confirm increased endothelial permeability, the endothelial junction was immunostained after the adhesion of BCs to non-activated p-HMVECs. A single cell suspension of MDA-MB-231 BCs was treated with sEselectin and then washed with PBS to remove sE-selectin. The cells were infused into a flow chamber at a rate of $1 \mathrm{dyn} / \mathrm{cm}^{2}$ for $5 \mathrm{~min}$. After a brief wash, the cells were fixed for immunostaining with VE-cadherin. The shearresistant adhesion of sE-selectin-treated MDA-MB-231 $\mathrm{BCs}$ to non-activated p-HMVECs resulted in the appearance of a visible gap and disappearance of VE-cadherin surface expression (Fig. 3b). These data suggest that the adhesion of sE-selectin treated $\mathrm{CD} 44^{+/ \text {high }}$ BCs permeabilizes non-activated endothelium.

\section{Soluble E-selectin activates focal adhesion kinase}

To determine the underlying mechanism of sE-selectinmediated adhesion and migration, a single cell suspension of MDA-MB-231 BCs was incubated with sE-selectin for 5 to $60 \mathrm{~min}$. Soluble E-selectin triggered the phosphorylation of focal adhesion kinase (FAK) at Tyr-397 after 5 min of incubation; whereas there were no changes in total FAK expression (Fig. 4a). However, sE-selectin did not affect FAK phosphorylation in the CD44sh 28 clone (Fig. 4a), suggesting the involvement of $\mathrm{CD} 44$ in sE-selectin-mediated FAK phosphorylation. To confirm the involvement of FAK signaling in sE-selectin-mediated effects, adhesion assays were performed using pathway-specific inhibitors at a concentration that did not affect cell viability (Additional file 1: Figure S2). Suspensions of MDAMB-231 or HL-60 cells were co-incubated with sEselectin and FAK inhibitor (FAK inhibitor II, $5 \mu \mathrm{M}$ ) for $30 \mathrm{~min}$. After a brief spin followed by washing with PBS, the cells were then infused into parallel flow chambers. FAK inhibitor II abolished sE-selectinmediated shear-resistant adhesion to non-activated HMVECs (Fig. 4b).

\section{Pre-activation of $4 \mathrm{~T} 1 \mathrm{BCs}$ with sE-selectin results in enhanced homing in vivo}

To validate the effect of sE-selectin on hematogenous metastasis, we used a mouse model of forced lung metastasis. Murine 4. T1 BCs expressing luciferase (4T1Luc) were pre-incubated with mouse sE-selectin and injected into wild-type Balb/C or E-selectin knockout mice via tail vein. Seven days after the injection, the mice were perfused with warm saline to remove residual

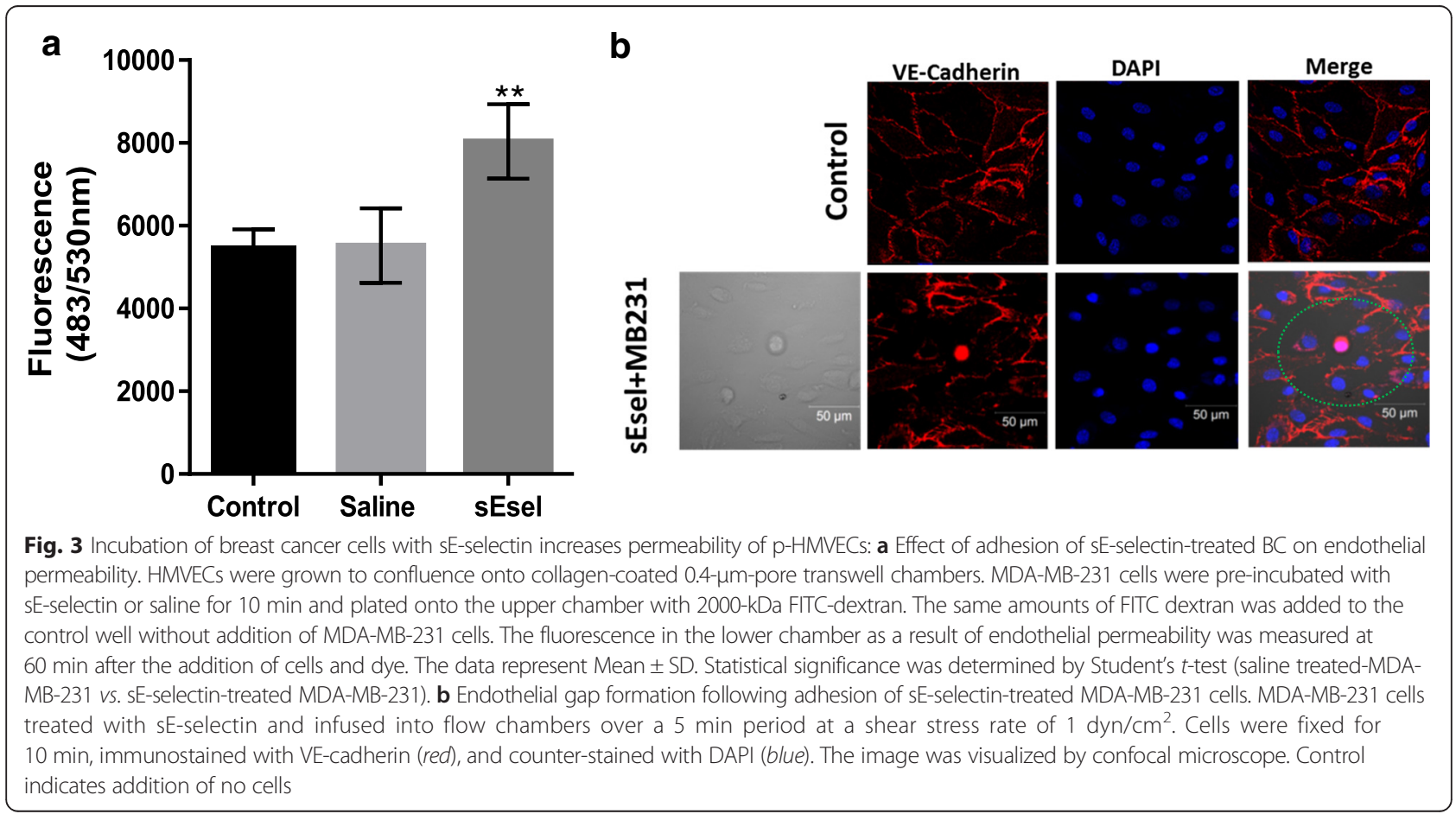




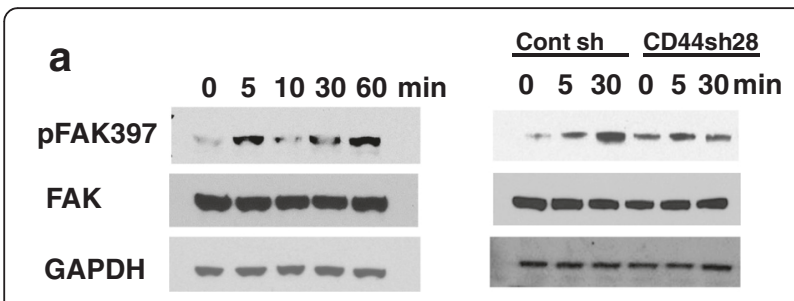

b

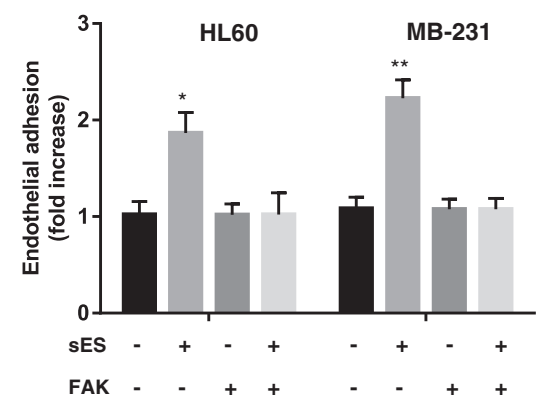

Fig. 4 Soluble E-selectin triggers FAK activation: a Activation of FAK by sE-selectin in MDA-MB-231. An MDA-MB-231 suspension was incubated with sE-selectin $(100 \mathrm{nM})$ for the indicated period of time (0-60 min). CD44 shRNA knockdown clones or control shRNA of MDA-MB-231 cells (clone 28) were incubated with sE-selectin for the indicated time. Cell lysate $(30 \mu \mathrm{g})$ was separated by SDS-PAGE and probed with pFAK (Y397) and total FAK, followed by HRP-conjugated secondary antibody. GAPDH was used as a loading control. The blot was visualized by ECL. b FAK inhibitor blocks sE-selectin-mediated adhesion. MDA-MB-231 or HL-60 cells were co-incubated with vehicle alone, sE-selectin, FAK inhibitor II (5 $\mu \mathrm{M})$, or sE-selectin + FAK inhibitor II for $30 \mathrm{~min}$ in a rotation wheel. After a brief wash with PBS, the cells were infused into parallel flow chambers over a 5 min period at a shear stress rate of $1 \mathrm{dyn} / \mathrm{cm}^{2}$. The adherent cells were counted under a microscope. The data were summarized as fold increase of adhesion of MDA-MB-231 and HL60 cells. The data represent Mean \pm SD. Statistical significance was determined by Student's t-test

cells in the circulation. Relative luciferase mRNA expression was measured in the lung. Pre-incubation of 4 T1 cells with sE-selectin increased homing to the lung by 2.5 fold $(p=0.03)$ in wild-type mice and 1.7 fold $(p=0.04)$ in E-selectin knockout mice compared with saline-treated 4 T1-Luc (Fig. 5a). The increased extent of lung homing in wild-type mice may be a consequence of endogenous E-selectin expression on the vessel or sE-selectin shed after activation in wild-type mice. To identify cellular adhesion molecules (CAMs) that support endothelial E-selectin-independent/sEselectin-mediated shear-resistant adhesion, functional blocking antibodies against ICAM or VCAM were used to pretreat non-activated p-HMVECs for $1 \mathrm{~h}$ prior to the flow adhesion assay. The pre-incubation of non-activated p-HMVECs with ICAM-1 blocking antibody resulted in a significant reduction of $\mathrm{sE}$ selectin-mediated shear-resistant adhesion; whereas, VCAM-1 blockade did not affect sE-selectin-mediated shear-resistant adhesion (Fig. 5b).

\section{Pre-activation of human PBMCs with sE-selectin stimulates} tumor growth

To confirm pleiotropic effects of sE-selectin, we next explored the biological consequences of leukocyte activation by sE-selectin on tumor growth in vivo. Human PBMCs were freshly isolated from healthy donors and labeled with Calcein AM, then pre-treated with sE-selectin for $30 \mathrm{~min}$ at $37{ }^{\circ} \mathrm{C}$. The PBMCs were infused via tail vein into NSG mice bearing human breast tumors derived from MDA-MB-231. Infiltration of Calcein positive PBMCs was measured by fluorescence-activated cell sorting (FACS) and visualized by fluorescent microscopy. Following a single intravenous infusion of sE-selectin-treated PBMCs, $1.45 \pm 0.08 \%$ of tumor cells were Calceinpositive, whereas, only $0.14 \pm 0.1 \%$ of tumor cells were Calcein-positive in mice receiving saline-treated PBMCs. This amounts to a ten-fold increase in PBMC infiltration when PBMCs are exposed to sE-selectin prior to infusion $(p<0.001)$ (Fig. 6a). Fluorescence microscopic analysis further confirmed that pre-incubation of PBMCs with sEselectin resulted in an increased infiltration of Calceinpositive PBMCs into tumors, compared with tumor from mice infused with saline-treated PBMCs (Fig. 6a). Next, we evaluated whether the infiltration of sE-selectintreated PBMCs into the tumor affected tumor growth. PBMCs treated with or without sE-selectin were infused at day 18 and 25 into NSG mice bearing MDA-MB-231 breast tumors carrying the luciferase gene $(n=5)$. Tumor growth was measured weekly at day 10, 16, 22 and 29 by bioluminescence. PBMCs were infused, and on day 22 (4 days post- PBMC infusion), we found that infusion of sE-selectin-treated PBMCs had increased tumor growth by 3.6 fold when compared to day 16 (prior to infusion). In contrast, in the mice receiving saline-treated PBMCs, only 1.4 fold tumor growth was noted. The differences in tumor growth rates between these groups were significant at four days after infusion (2.6 fold, $p<0.05$ ). This trend remained the same at 29 days (Fig. 6b). FACS analysis of tumors further confirmed the presence of human CD45+ cells after two consecutive infusions of human PBMCs (Fig. 6c). Infusion of sE-selectin treated of PBMCs increased intratumoral infiltration by human $\mathrm{CD} 4+\mathrm{T}$ lymphocytes $(20.2 \%)$ significantly more than infusion of saline treated control PBMCs (11.5\%), but did not affect infiltration of CD8+ T-lymphocytes or CD68+ cells. Of note, the CD4/CD8 ratios of PBMCs used in this study were almost the same (CD4: 39.1, CD8: 37.2; Additional file 1: Figure S3). These data suggest that $\mathrm{sE}$-selectin is a biologically functional signaling molecule in circulation after shedding and enhances the shear-resistant adhesion and migration of a broad range of CD44+ circulating cells (metastatic cancer cells or leukocytes), which additively promote disease progression via stromal development and homing of metastatic BCs to the lung. 

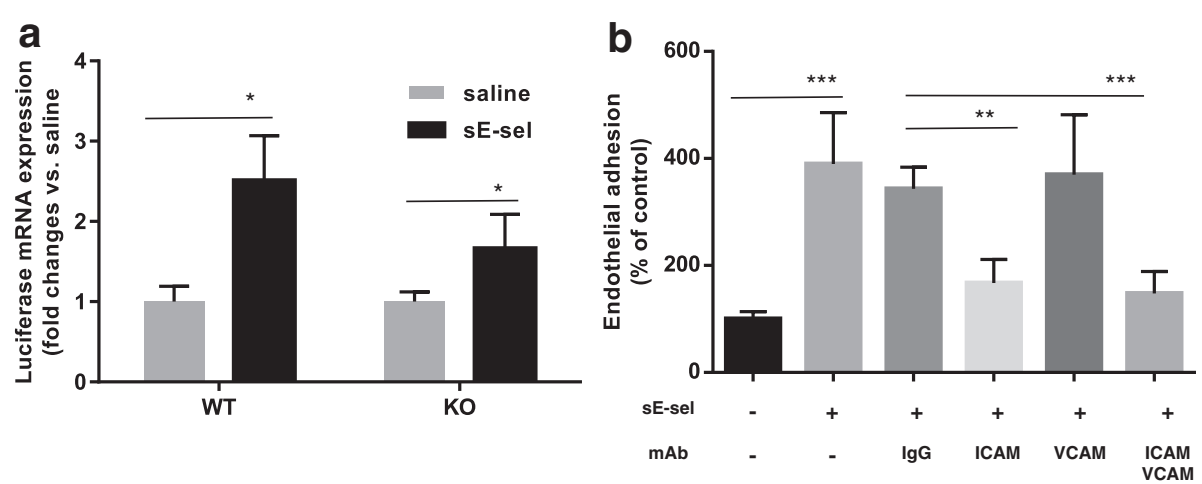

Fig. 5 Soluble E-selectin enhances homing of 4T1 cells to the lung in mice: a Effect of sE-selectin on infiltration of 4 T1 cells into the lung. Luciferaseexpressing $4 \mathrm{~T} 1$ murine breast cancer cells were pre-incubated with sE-selectin (100 nM) and, following washing with PBS to eliminate sE-selectin carryover, were intravenously injected into female Balb/C or E-selectin knockout mice. Seven days later, lungs were harvested and luciferase mRNA was analyzed by qRT-PCR and normalized by GAPDH. The data represent Mean \pm SD. Statistical significance was determined by Student's $t$-test. b sE-selectin-mediates adhesion is ICAM-1 dependent. Parental-HMVECs were pre-incubated with monoclonal antibody $(1 \mu \mathrm{g}$ in $100 \mu \mathrm{l})$ against ICAM-1 or VCAM-1 or the same amount of normal lgG for $1 \mathrm{~h}$ at $37^{\circ} \mathrm{C}$ prior to the adhesion assay. After a brief wash, MDA-MB-231 BCs that were treated with sE-selectin for 30 min were infused into parallel flow chambers. The data represent Mean \pm S.D. ${ }^{* *} p<0.01$; ${ }^{* * *} p<0.001$ vs. $/-$, Student's $t$ test. Data were summarized as $\%$ of control (-/-) from an experiment conducted in triplicate, and repeated twice
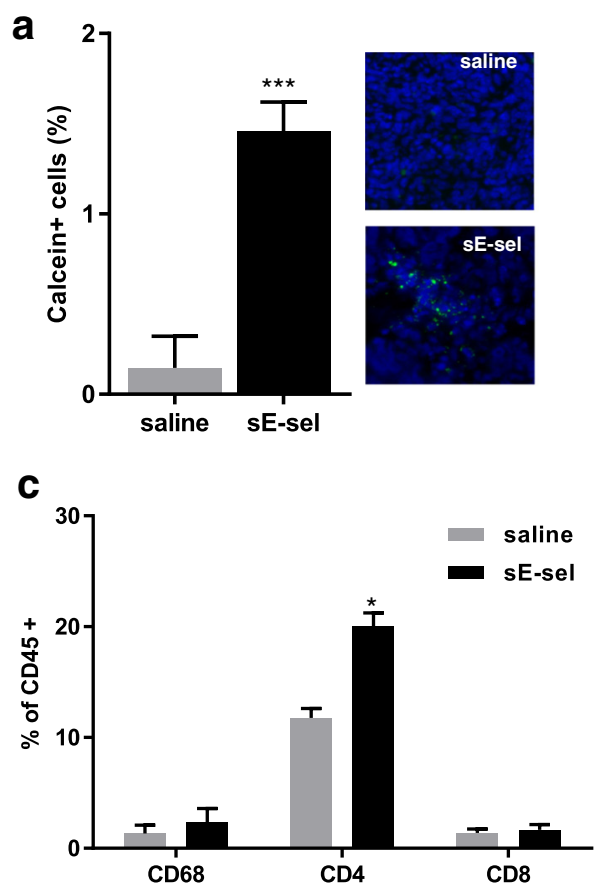

b

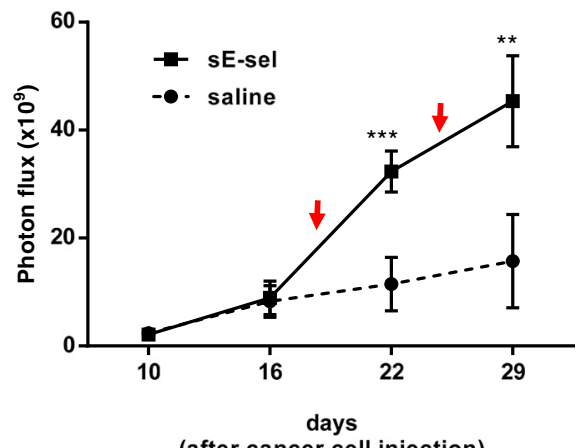

(after cancer cell injection)

Fig. 6 Soluble E-selectin enhances infiltration of PBMCs into tumor and tumor growth in NSG mice: a Human PBMC infiltration into breast tumor. Freshly isolated PBMCs were labeled with Calcein AM, followed by incubation with $100 \mathrm{nM}$ sE-selectin for $15 \mathrm{~min}$. After a brief washing to eliminate sE-selectin carryover, PBMCs $\left(2 \times 10^{7}\right.$ cells) were infused into NSG mice bearing orthotopic breast tumors derived from MDA-MB-231 breast cancer cells $(n=4)$. Tumors were isolated 4 days after PBMC infusion and the numbers of Calcein-positive cells were counted by FACS. The histogram represents Mean \pm SE ( $n=4$ mice). Frozen sections $(5 \mu \mathrm{m})$ were stained with Hoechst 33342 (blue) to label nuclei. $\mathbf{b}$ Tumor growth following PBMC infusion. MDA-MB-231-luc cells was injected into mammary fat pad of NSG mice at day 0 and tumor growth was measured at day 10 and 16 to confirm similar growth rate between two groups. On day 18 and 25, human PBMCs ( $10^{7}$ cells) were infused via tail vein (red arrow) and tumor growth after the infusion was measured on day 22 and 29. Tumor growth was measured using bioluminescent imaging. The graph indicates photon flux from mice infused with PBMCs pre-incubated with saline (dashed line) or $100 \mathrm{nM}$ sE-selectin (solid line). The data represent Mean \pm SE $(n=5)$. c FACS analysis of human CD45+ leukocyte populations in the tumor. Tumors were harvested and single cell suspensions were labeled with human CD45, CD4, CD8, and CD68, and were analyzed by flow cytometry 


\section{Discussion}

Circulating E-selectin, sE-selectin, is a byproduct of endothelial E-selectin that originates from the external domain of E-selectin expressed on activated endothelium as a result of enzymatic cleavage or shedding from damaged or activated endothelial cells [29]. Several studies have reported chemotactic effects of sE-selectin in different cell types, including endothelial cells and leukocytes [30-32]. However, the effects of sE-selectin in tumor progression and metastasis is largely unknown. We and others have previously reported that the engagement of CD44 with endothelial E-selectin mediates shear-resistant adhesion of BCs and leukocytes to endothelial cells [13, 14, 33]. In addition to describing the roles of endothelial E-selectin, we found that sEselectin functions as a circulating signaling molecule that potentiates shear-resistant adhesion and migration of CD44 $4^{+/ h i g h} \mathrm{BCs}$ and leukocytes in an endothelial E-selectin independent fashion and facilitates tumor progression and metastasis.

The adhesion cascade is governed by cell-cell interactions between circulating cells and endothelial cells via a sequential affinity interaction between adhesion molecules and the counter-receptor ligand. Thus, the ablation of adhesion molecules, such as selectins, ICAM-1, or VCAM-1, significantly impairs leukocyte infiltration. Given the E-selectin's integral role in tissue infiltration as the first step mediator of adhesion, endothelial Eselectin-independent homing and shear-resistant adhesion of BCs and leukocytes were unexpected. Our data demonstrate that sE-selectin-mediated activation of the CD44/FAK axis of BCs enables ICAM-1-dependent adhesion at low shear stress, bypassing the requirement for engagement with endothelial E-selectin. A bypass of initial adhesion via endothelial E-selectin may occur when abundant $\mathrm{CD} 44^{+}$cells and circulating sE-selectin encountered endothelium expressing ICAM-1 at low shear stress. Similar bypass mechanism was reported by Thankamony and Sackstein as a novel paradigm of cell migration termed the "step 2-bypass pathway"'. The step 2-bypass pathway permits transendothelial migration of mesenchymal stem cells through interaction of endothelial VCAM-1 with activated VLA-4 without engagement of the chemokine receptors (CXCR4 and SDF-1) [34]. These data suggest the presence of alternative adhesion mechanisms that are supported by CAMs. In fact, the expression of CAMs is primarily induced by inflammatory cytokines; however, low levels of constitutive expression occurs in some organs and endothelial cell lines [35-37]. Additionally, double knockout of ICAM/ VCAM is lethal $[38,39]$, while triple knockout of selectins (E-, P-, and L-selectin) does not completely ablate tissue infiltration of leukocytes to wounded areas [40]. These collectively indicate the presence of a selectin- independent alternative adhesion, which may be compensated by constitutive CAMs expression. This poses the question of whether individuals with breast cancer and synchronous chronic inflammation who have elevated sEselectin and CD44+ circulating tumor cells (CTCs) are predisposed to increased risk of organ metastasis. Our data suggested that serum sE-selectin levels were associated with tumor size (Additional file 1: Figure S4). Additionally, several studies demonstrated positive correlations between high sE-selectin levels and worse clinical outcome [25, 4143]. Sheen-Chen et al., reported that an elevated level of sE-selectin is significantly associated with advanced tumor size, lymph node involvement, metastasis, high histology grade, and reduced overall survival in breast cancer. The study further indicated that women with ER-negative breast tumors had a significantly higher level of sE-selectin than those with ER-positive breast tumors [41]. Similarly to cancer, elevated sE-selectin was also noted in individuals with chronic inflammation disorders including arthritis [44], diabetes [45], atherosclerosis [46], and alcoholism [47]. Our data demonstrated cellular responses to sE-selectin were concentration dependent and reached a plateau at $100 \mathrm{nM}$ (Additional file 1: Figure S5); therefore, we used $100 \mathrm{nM}$ sE-selectin in this study (equal to approx. $5.8 \mu \mathrm{g} / \mathrm{ml}$ when calculated as MW: $60 \mathrm{kDa}$ ). While the association of tissue inflammation and cancer progression has been reported [48, 49], future study should address a possible link regarding how chronic inflammation affects cancer cell behavior in vascular space.

The effect of sE-selectin was highly specific to CD $44^{+/ \text {high }}$ $\mathrm{BCs}$; its effect was minor or undetectable in CD44-/low $\mathrm{BCs}$ and CD44 K/D MDA-MB-231 BCs. CD44 (HCELL) [34], belongs to a family of cell-surface glycoproteins, and differential forms of CD44 (e.g., CD44s and CD44v) are expressed in a variety of human leukocytes and solid tumors. Despite its lack of intrinsic catalytic activity, CD44 plays a role in the activation of signaling pathways through association with intracellular and extracellular proteins. CD44 interacts with various soluble extracellular components or ECM. Ligand binding to CD44 has been associated with numerous cellular processes such as migration, adhesion, signaling, and proliferation [50]. For example, the interaction of CD44 and its ligand, hyaluronic acid (HA), results in proliferation of eosinophils [51], B-cells [52], T-cells [53], keratinocytes [54], and human melanoma cells [55]. In addition to HA, L-selectin and E-selectin are reported to be ligands for distinct glycoforms of CD44 or CD44v, respectively [56]. The interaction of CD44 with Src family protein kinase, Rho-kinase, Tiam 1, and Vav2 triggers intracellular activation of PI3K, Ras, and Rac1, which promote cell migration, proliferation, and survival [57-61]. Although mounting evidence suggests the involvement CD44 in tumor progression, the roles of CD44 as well as 
its utility as a biomarker for primary tumors remains controversial due to its dual functions as a tumor promoter or suppressor and altered expression in CD44v [37, 38]. However, recent studies highlighted the positive association of $\mathrm{CD} 44^{+} \mathrm{CTCs}$ with hematogenous metastasis. The presence of CD44 ${ }^{+}$CTCs is linked to bone metastasis [62] and correlates with poor prognosis in breast cancer $[63,64]$. While the CD44 has been used as a stem cell marker, our data suggest that CD44 may have functional role in hematogenous metastasis in the circulation 1) as a ligand for endothelial E-selectin at the pre-metastatic niche [13] and 2) as a signaling molecule that mediates sE-selectininduced extrinsic stimuli in circulating cells.

Abundant leukocyte infiltration into the tumor is associated with poor prognosis in many types of cancer including breast, prostate, lung cancer, and melanoma [48, 65, 66]. Our results demonstrate that sE-selectin enhancement of leukocyte migration is partially mediated by $\mathrm{CD} 44$. We used humanized NOD SCID IL2R- $\gamma$ chain knockout mice, which are deficient in T-lymphocytes, B-lymphocytes, and NK cells, to recapitulate the effect of crosstalk between the human immune system and human cancer cells. Mice receiving human PBMCs treated with human sEselectin showed rapid tumor growth, which coincided with increased intratumoral infiltration of PBMCs, in particular, $\mathrm{CD} 4^{+}$T-lymphocytes (Fig. 6c). Although we expected the $\mathrm{CD} 4+/ \mathrm{CD} 8+$ balance shift to trigger proinflammatory signaling that would lead to an increase in the human CD68+ macrophage population, no change was noted in $\mathrm{CD} 68+$ cells or CD8+ T-lymphocytes. A separate study showed that $\mathrm{sE}$-selectin-mediated tumor growth was not as significant when mouse splenocytes were infused into athymic nu/nu mice bearing xenograft tumors derived from MDA-MB-231 cells (data not shown), although infiltration of mouse PBMCs into the tumor was more extensive than that of human PBMCs (Additional file 1: Figure S6). Possibly, there is a slight discordance between adaptive immune cells from human and innate immune cells and vessels of mice.

In conclusion, we proposed possible simultaneous and multifaceted effects of E-selectin in tumor growth and metastasis in Fig. 7: endothelial E-selectin mediates the shear-resistant adhesion of circulating tumor cells and immune cells to inflamed vessels (a), but not to noninflamed vessels (b); sE-selectin shed into circulation accelerates homing of $\mathrm{CD} 44^{+} \mathrm{BCs}$ into tissue via noninflamed vessels, endothelial E-selectin independent/ ICAM dependent manner (c); sE-selectin accelerates the infiltration of CD4+ lymphocytes into the tumor to contribute to the development of inflammatory stromal (d).

\section{Conclusion}

Soluble E-selectin (sE-selectin) is shed into the circulation from the activated endothelium. We investigated the effect of sE-selectin on shear-resistant adhesion and migration of metastatic breast cancer cells and leukocytes. Our data suggest that $\mathrm{sE}$-selectin promotes migration and shear-
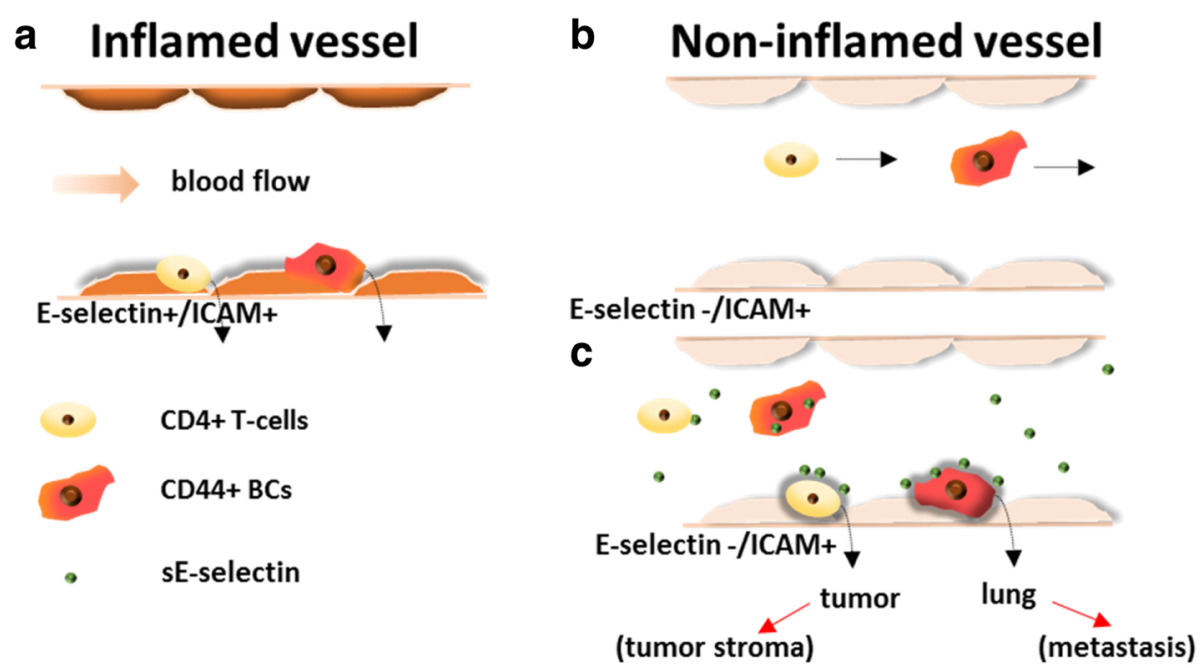

Fig. 7 Scheme of sE-selectin-mediated shear-resistant adhesion and migration: a The expression of adhesion molecules such as E-selectin, ICAM, and VCAM is induced in the luminal surface of inflamed vessel. Margination of leukocytes and CD $44^{+/ \text {high }}$ BCs toward the vessel surface is followed by tethering, rolling, and adherence to inflamed vessels. The adhesion of the cells increases the permeability of endothelial junctions facilitating tissue migration of circulating cells. b By contrast, in a non-inflamed vessel, circulating cells remain in circulation and no random adhesion occurs. c Soluble E-selectin is shed from activated endothelium of inflamed tissues and activates both leukocytes and CD44 ${ }^{+/ \text {high }} \mathrm{BCs}$, which enhances their shear resistant adhesion to non-inflamed vessels and migration in the absence of E-selectin but via interaction with ICAM at low shear stress. Excessive infiltration of CD4 ${ }^{+}$ T-lymphocytes into the tumor leads to development of pro-tumorigenic stroma. Infiltration of CD44 ${ }^{\text {thigh }} \mathrm{BCs}$ into distant organ increases the risk of colonization by metastatic cells 
resistant adhesion of circulating cells to non-activated HMVECs via CD44/FAK. This sE-selectin-mediated pleiotropic effects result in enhancement of homing of $\mathrm{CD} 44^{+/ \text {high }} \mathrm{BCs}$ and immune cells to the lung and tumor, respectively. These findings identify a possible extrinsic mechanism by which serum factor stimulates circulating tumor cells toward tumor progression and metastasis.

\section{Additional files}

Additional file 1: Supplementary Figure 1. Soluble E-selectin enhances the anoikis resistance of ER-negative BCs: BCs were suspended (104 cells) in 1\% FBS media with or without sE-selectin, and seeded in ultra-low attachment plates. The data represent the increased percentage of surviving cells with $s E-$ selectin. The data shown are Mean \pm SD. Supplementary Figure 2. The effect of FAK kinase inhibitors on cell viability: (a) HL-60 cells were incubated with the indicated concentrations of FAK inhibitor for $30 \mathrm{~min}$. The viable cells were counted using a Neubauer hemocytometer 24 hours later. (b) MDA-MB-231 cells were incubated with the indicated concentrations of FAK inhibitor for $30 \mathrm{~min}$. The cell viability was measured by MTT assay. Supplementary Figure $\mathbf{3}$. Profile of human PBMCs: PBMCs were isolated from freshly isolated human buffy coat of healthy donors. PBMCs were analyzed by flow cytometry using a FACS Calibur. Supplementary Figure 4. Detection of sE-selectin in the serum from mice bearing tumor: MDA-MB-231 cells ( $3 \times 104$ or $3 \times 105$ cells) were injected into mice $(n=4)$. Two weeks later, whole blood was collected and serum was collected. Soluble E-selectin level was measured by ELISA. The data shown are Mean \pm SD.

Supplementary Figure 5. Soluble E-selectin enhances migration of MDA-MB-231 in sE-selectin dose dependent manner: Boyden chamber assay was performed. The migrated cells were stained using an HEMA3 staining kit and were counted under light microscopy. Data were expressed as percentage of control (saline treated as 100\%). The data represent Mean \pm S.D. Supplementary Figure 6 . Mouse splenocyte infiltration into human tumor: Mouse splenocytes were isolated from Athymic nu/nu mice and labeled with Calcein AM (green). The labeled splenocytes (107 cells) were infused intravenously into mice bearing tumors derived from MDA-MB-231 BCs. Tumors were harvested and frozen sections were counterstained with Hoechst 33342 (blue) and visualized using a fluorescent microscope at $\times 200$. (PPTX $4183 \mathrm{~kb}$ )

\section{Abbreviations}

BCs: breast cancer cells; CAMs: cell adhesion molecules; CD11cAPC: allophycocyanin-conjugated CD11c antibody; CD14-PE: phycoerythrinconjuated CD14 antibody; CD44 KD: CD44 knock down; CD44: homing cell adhesion molecule (HCAM), phagocytic glycoprotein-1(Pgp-1); CD44s: CD44 standard from; CD44sh: shRNA targeting CD44; CD44v: CD44 variant isoforms; CD45-FITC: fluorescein isothiocyanate-conjugated CD44 antibody; CD4-APC-eFluor780: allophycocyanin-eFluor780-conjugated CD4 antibody; CD68+: cluster of differentiation 68 positive; CD8-PerCPCy5.5: peridinin chlorophyll-cyanine5.5-conjugated antibody; CXCR4: Chemokine receptor 4; DMEM: Dulbecco's modified eagle medium; dyn/cm2: dyne per one square centimeter; ER+: estrogen receptor positive; E-selectin: endothelial leukocyte adhesion molecule, CD62E; ESL-1: E-selectin ligand 1; FAK: Focal adhesion kinase; FITC: fluorescein isothiocyanate; GAPDH: glyceraldehyde-3-phosphate dehydrogenase; HCELL: hematopoietic cell E-selectin/L-selectin Ligand; HMVECs: human microvessel endothelial cells; ICAM: Intercellular adhesion molecules; Muc-1: Mucin 1; NSG mice: NOD scid gamma mice; PBMCs: peripheral blood mononuclear cells; pFAK: phosphorylated focal adhesion kinase; pHMVEC: parental HMVECs; PI3K: phosphoinositide 3-kinase; Rac1: ras-related C3 botulinum toxin substrate 1; Ras: rat sarcoma viral oncogene; SDF-1: stromal cell-derived factor 1; sE-selectin: soluble E-selectin; Src: proto-oncogene tyrosine kinase; VCAM: vascular cell adhesion molecules; VE-cadherin: vascular endothelial cadherin; VLA-4: very late antigen-4 (Integrin alpha4 beta1).

\section{Acknowledgements}

We thank Mrs. Lynsie Morris for technical assistance.

\section{Funding}

This work was supported by the Department of Defense (W81XWH-11-10238 to T.T), the National Institutes of Health (1R01CA160271-01A1 to T.T), the American Cancer Society (IRG-08-060-04), and the Pennsylvania Breast Cancer Coalition (T.T).

\section{Authors' contributions}

SK and CB have made substantial contributions to design and/or acquisition of data, or data analysis and interpretation of data. SB, NH, VG, BT, MK, and YM have been involved in data acquisition, revising it critically for important content. TT, HR, WR, DG, and KSS have been involved in drafting the concept, manuscript, and given final approval of the version to be published. All authors have read and approved the contents of final version of the manuscript.

\section{Competing interest}

The authors declare that they have no competing interests.

\section{Consent for publication}

All authors have read and approved the contents of final version of the manuscript and consented for publication.

\section{Ethics approval and consent to patients}

Animal studies received specific ethical institutional committee approval from Institutional Animal Care and Use Committee of the Thomas Jefferson University and University of Oklahoma. All cell lines used in this study were obtained from commercial sources or investigator under MTA agreement; no clinical specimens or human subjects were employed.

\section{Author details}

${ }^{1}$ Department of Pathology, University of Oklahoma Health Sciences Center, 975 NE, 10th, Oklahoma City, OK 73104, USA. ${ }^{2}$ Thomas Jefferson University, Pharmaceutical Sciences, 1020 Locust St, Philadelphia, PA 19107, USA. ${ }^{3}$ John Theurer Cancer Center, Hackensack University Medical Center, Hackensack, NJ 07601, USA. ${ }^{4}$ Institute of Molecular Medicine, University of Texas Health Science Center at Houston, 1825 Hermann Pressler, Houston, TX 77030, USA. ${ }^{5}$ Department of Internal Medcine, Stephenson Cancer Center, University of Oklahoma Health Sciences Center, 800 NE, 10th, Oklahoma City, OK 73104 , USA. ${ }^{6}$ Department of Pathology, Medical College of Wisconsin Cancer Center, 8701 Watertown Plank Rd, Milwaukee, WI 53226, USA. ${ }^{7}$ Stephenson Cancer Center at the University of Oklahoma Health Sciences Center, 975 NE 10th, Oklahoma City, OK 73104, USA.

Received: 21 December 2015 Accepted: 17 May 2016

Published online: 24 May 2016

\section{References}

1. Berg EL, Robinson MK, Mansson O, Butcher EC, Magnani JL. A carbohydrate domain common to both sialyl Le(a) and sialyl Le $(X)$ is recognized by the endothelial cell leukocyte adhesion molecule ELAM-1. J Biol Chem. 1991;266(23): 14869-72.

2. Welply JK, Keene JL, Schmuke JJ, Howard SC. Selectins as potential targets of therapeutic intervention in inflammatory diseases. Biochim Biophys Acta. 1994;1197(2):215-26.

3. Zetter BR. Adhesion molecules in tumor metastasis. Semin Cancer Biol. 1993;4(4):219-29.

4. Nguyen DX, Bos PD, Massague J. Metastasis: from dissemination to organ-specific colonization. Nat Rev Cancer. 2009;9(4):274-84

5. Luster $A D$, Alon $R$, von Andrian $U H$. Immune cell migration in inflammation: present and future therapeutic targets. Nat Immunol. 2005;6(12):1182-90

6. Ley K, Laudanna C, Cybulsky MI, Nourshargh S. Getting to the site of inflammation: the leukocyte adhesion cascade updated. Nat Rev Immunol. 2007;7(9):678-89.

7. Laubli H, Borsig L. Selectins promote tumor metastasis. Semin Cancer Biol. 2010;20(3):169-77.

8. Woodward J. Crossing the endothelium: E-selectin regulates tumor cell migration under flow conditions. Cell Adh Migr. 2008;2(3):151-2. 
9. Bevilacqua MP. Endothelial-leukocyte adhesion molecules. Annu Rev Immunol. 1993;11:767-804.

10. Cotran RS, Gimbrone Jr MA, Bevilacqua MP, Mendrick DL, Pober JS. Induction and detection of a human endothelial activation antigen in vivo. J Exp Med. 1986;164(2):661-6.

11. Bevilacqua MP, Pober JS, Mendrick DL, Cotran RS, Gimbrone Jr MA. Identification of an inducible endothelial-leukocyte adhesion molecule. Proc Natl Acad Sci U S A. 1987;84(24):9238-42.

12. Dimitroff CJ, Lee JY, Rafii S, Fuhlbrigge RC, Sackstein R. CD44 is a major Eselectin ligand on human hematopoietic progenitor cells. J Cell Biol. 2001; 153(6):1277-86.

13. Kang SA, Hasan N, Mann AP, Zheng W, Zhao L, Morris L, Zhu W, Zhao D, Suh KS, Dooley WC, et al. Blocking the Adhesion Cascade at the Premetastatic Niche for Prevention of Breast Cancer Metastasis. Mol Ther. 2015; 23(6):1044-54

14. Zen K, Liu DQ, Guo YL, Wang C, Shan J, Fang M, Zhang CY, Liu Y. CD44v4 is a major E-selectin ligand that mediates breast cancer cell transendothelial migration. PLoS One. 2008;3(3):e1826.

15. Shirure VS, Reynolds NM, Burdick MM. Mac-2 binding protein is a novel E-selectin ligand expressed by breast cancer cells. PLoS One. 2012;7(9):e44529.

16. Geng Y, Yeh K, Takatani T, King MR. Three to Tango: MUC1 as a Ligand for Both E-Selectin and ICAM-1 in the Breast Cancer Metastatic Cascade. Front Oncolo. 2012;2:76.

17. Gout S, Morin C, Houle F, Huot J. Death receptor-3, a new E-Selectin counter-receptor that confers migration and survival advantages to colon carcinoma cells by triggering p38 and ERK MAPK activation. Cancer Res. 2006;66(18):9117-24.

18. Dimitroff CJ, Descheny L, Trujillo N, Kim R, Nguyen V, Huang W, Pienta KJ, Kutok JL, Rubin MA. Identification of leukocyte E-selectin ligands, P-selectin glycoprotein ligand-1 and E-selectin ligand-1, on human metastatic prostate tumor cells. Cancer Res. 2005;65(13):5750-60.

19. Gearing AJ, Hemingway I, Pigott R, Hughes J, Rees AJ, Cashman SJ. Soluble forms of vascular adhesion molecules, E-selectin, ICAM-1, and VCAM-1: pathological significance. Ann N Y Acad Sci. 1992;667:324-31.

20. Gearing AJ, Newman W. Circulating adhesion molecules in disease. Immunol Today. 1993;14(10):506-12.

21. Fassbender K, Mossner R, Motsch L, Kischka U, Grau A, Hennerici M. Circulating selectin- and immunoglobulin-type adhesion molecules in acute ischemic stroke. Stroke. 1995;26(8):1361-4.

22. Cowley HC, Heney D, Gearing AJ, Hemingway I, Webster NR. Increased circulating adhesion molecule concentrations in patients with the systemic inflammatory response syndrome: a prospective cohort study. Crit Care Med. 1994;22(4):651-7.

23. Koch AE, Turkiewicz W, Harlow LA, Pope RM. Soluble E-selectin in arthritis. Clin Immunol Immunopathol. 1993;69(1):29-35.

24. Leeuwenberg JF, Smeets EF, Neefjes JJ, Shaffer MA, Cinek T, Jeunhomme TM, Ahern TJ, Buurman WA. E-selectin and intercellular adhesion molecule-1 are released by activated human endothelial cells in vitro. Immunology. 1992;77(4):543-9.

25. Hebbar M, Revillion F, Louchez MM, Vilain MO, Fournier C, Bonneterre J, Peyrat JP. The relationship between concentrations of circulating soluble E-selectin and clinical, pathological, and biological features in patients with breast cancer. Clin Cancer Res. 1998;4(2):373-80.

26. Mann AP, Somasunderam A, Nieves-Alicea R, Li X, Hu A, Sood AK, Ferrari M, Gorenstein DG, Tanaka T. Identification of thioaptamer ligand against Eselectin: potential application for inflamed vasculature targeting. PloS one 2010;5(9):e13050.

27. Mierke CT. Endothelial cell's biomechanical properties are regulated by invasive cancer cells. Mol Biosyst. 2012;8(6):1639-49.

28. Sulzmaier FJ, Jean C, Schlaepfer DD. FAK in cancer: mechanistic findings and clinical applications. Nat Rev Cancer. 2014;14(9):598-610.

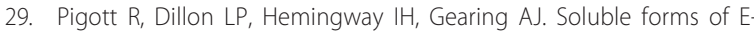
selectin, ICAM-1 and VCAM-1 are present in the supernatants of cytokine activated cultured endothelial cells. Biochem Biophys Res Commun. 1992;187(2):584-9.

30. Lo SK, Lee S, Ramos RA, Lobb R, Rosa M, Chi-Rosso G, Wright SD. Endothelial-leukocyte adhesion molecule 1 stimulates the adhesive activity of leukocyte integrin CR3 (CD11b/CD18, Mac-1, alpha m beta 2) on human neutrophils. J Exp Med. 1991;173(6):1493-500.
31. Kumar P, Hosaka S, Koch AE. Soluble E-selectin induces monocyte chemotaxis through Src family tyrosine kinases. J Biol Chem. 2001;276(24): 21039-45.

32. Koch AE, Halloran MM, Haskell CJ, Shah MR, Polverini PJ. Angiogenesis mediated by soluble forms of E-selectin and vascular cell adhesion molecule-1. Nature. 1995;376(6540):517-9.

33. Katayama Y, Hidalgo A, Chang J, Peired A, Frenette PS. CD44 is a physiological E-selectin ligand on neutrophils. J Exp Med. 2005;201(8): 1183-9.

34. Thankamony SP, Sackstein R. Enforced hematopoietic cell E- and L-selectin ligand (HCELL) expression primes transendothelial migration of human mesenchymal stem cells. Proc Natl Acad Sci U S A. 2011;108(6):2258-63.

35. Henninger DD, Panes J, Eppihimer M, Russell J, Gerritsen M, Anderson DC, Granger DN. Cytokine-induced VCAM-1 and ICAM-1 expression in different organs of the mouse. J Immunol. 1997;158(4):1825-32.

36. Fox SB, Turner GD, Gatter KC, Harris AL. The increased expression of adhesion molecules ICAM-3, E- and P-selectins on breast cancer endothelium. J Pathol. 1995;177(4):369-76.

37. Schweitzer KM, Drager AM, van der Valk P, Thijsen SF, Zevenbergen A Theijsmeijer AP, van der Schoot CE, Langenhuijsen MM. Constitutive expression of E-selectin and vascular cell adhesion molecule-1 on endothelial cells of hematopoietic tissues. Am J Pathol. 1996;148(1):165-75.

38. Gurtner GC, Davis V, Li H, McCoy MJ, Sharpe A, Cybulsky MI. Targeted disruption of the murine VCAM1 gene: essential role of VCAM-1 in chorioallantoic fusion and placentation. Genes Dev. 1995;9(1):1-14.

39. Kwee L, Baldwin HS, Shen HM, Stewart CL, Buck C, Buck CA, Labow MA. Defective development of the embryonic and extraembryonic circulatory systems in vascular cell adhesion molecule (VCAM-1) deficient mice. Development. 1995;121(2):489-503.

40. Robinson SD, Frenette PS, Rayburn H, Cummiskey M, Ullman-Cullere M, Wagner DD, Hynes RO. Multiple, targeted deficiencies in selectins reveal a predominant role for P-selectin in leukocyte recruitment. Proc Natl Acad Sci U S A. 1999;96(20):11452-7.

41. Sheen-Chen SM, Eng HL, Huang CC, Chen WJ. Serum levels of soluble Eselectin in women with breast cancer. Br J Surg. 2004;91(12):1578-81.

42. Eichbaum MH, de Rossi TM, Kaul S, Bastert G. Serum levels of soluble Eselectin are associated with the clinical course of metastatic disease in patients with liver metastases from breast cancer. Oncol Res. 2004;14(11-12): 603-10

43. O'Hanlon DM, Fitzsimons H, Lynch J, Tormey S, Malone C, Given HF. Soluble adhesion molecules (E-selectin, ICAM-1 and VCAM-1) in breast carcinoma. Eur J Cancer. 2002;38(17):2252-7.

44. Klimiuk PA, Fiedorczyk M, Sierakowski S, Chwiecko J. Soluble cell adhesion molecules (sICAM-1, sVCAM-1, and sE-selectin) in patients with early rheumatoid arthritis. Scand J Rheumatol. 2007;36(5):345-50.

45. Cakar M, Balta S, Sarlak H, Akhan M, Demirkol S, Karaman M, Ay SA, Kurt O, Cayci T, Inal S, et al. Arterial stiffness and endothelial inflammation in prediabetes and newly diagnosed diabetes patients. Arch Endocrinol Metab. 2015;59(5):407-13.

46. Kvasnicka T, Kvasnicka J, Ceska R, Grauova B, Vrablik M. Increasing plasma levels of soluble cell adhesion molecules (sE-Selectin, sP-Selectin and sICAM-1) in overweight adults with combined hyperlipidemia. Sb Lek. 2001; 102(4):473-7.

47. Sacanella E, Estruch R, Badia E, Fernandez-Sola J, Nicolas JM, UrbanoMarquez A. Chronic alcohol consumption increases serum levels of circulating endothelial cell/leucocyte adhesion molecules E-selectin and ICAM-1. Alcohol Alcohol. 1999;34(5):678-84.

48. Coussens LM, Werb Z. Inflammation and cancer. Nature. 2002;420(6917): 860-7.

49. Karin $M$, Lawrence $T$, Nizet $V$. Innate immunity gone awry: linking microbial infections to chronic inflammation and cancer. Cell. 2006;124(4):823-35.

50. Naor D, Sionov RV, Ish-Shalom D. CD44: structure, function, and association with the malignant process. Adv Cancer Res. 1997;71:241-319.

51. Hamann KJ, Dowling TL, Neeley SP, Grant JA, Leff AR. Hyaluronic acid enhances cell proliferation during eosinopoiesis through the CD44 surface antigen. J Immunol. 1995;154(8):4073-80.

52. Rafi A, Nagarkatti M, Nagarkatti PS. Hyaluronate-CD44 interactions can induce murine B-cell activation. Blood. 1997;89(8):2901-8.

53. Galandrini R, Galluzzo E, Albi N, Grossi CE, Velardi A. Hyaluronate is costimulatory for human $T$ cell effector functions and binds to CD44 on activated T cells. J Immunol. 1994;153(1):21-31. 
54. Kaya G, Rodriguez I, Jorcano JL, Vassalli P, Stamenkovic I. Selective suppression of CD44 in keratinocytes of mice bearing an antisense CD44 transgene driven by a tissue-specific promoter disrupts hyaluronate metabolism in the skin and impairs keratinocyte proliferation. Genes Dev. 1997;11(8):996-1007.

55. Ahrens T, Assmann V, Fieber C, Termeer C, Herrlich P, Hofmann M, Simon JC. CD44 is the principal mediator of hyaluronic-acid-induced melanoma cell proliferation. J Invest Dermatol. 2001;116(1):93-101.

56. Dimitroff CJ, Lee JY, Fuhlbrigge RC, Sackstein R. A distinct glycoform of CD44 is an L-selectin ligand on human hematopoietic cells. Proc Natl Acad Sci U S A. 2000;97(25):13841-6.

57. Ilangumaran S, Briol A, Hoessli DC. CD44 selectively associates with active Src family protein tyrosine kinases Lck and Fyn in glycosphingolipid-rich plasma membrane domains of human peripheral blood lymphocytes. Blood. 1998:91(10):3901-8.

58. Bourguignon LY, Zhu H, Shao L, Chen YW. CD44 interaction with tiam1 promotes Rac1 signaling and hyaluronic acid-mediated breast tumor cell migration. J Biol Chem. 2000;275(3):1829-38.

59. Bourguignon LY, Zhu H, Shao L, Chen YW. CD44 interaction with c-Src kinase promotes cortactin-mediated cytoskeleton function and hyaluronic acid-dependent ovarian tumor cell migration. J Biol Chem. 2001:276(10):7327-36.

60. Bourguignon LY, Zhu H, Zhou B, Diedrich F, Singleton PA, Hung MC. Hyaluronan promotes CD44v3-Vav2 interaction with Grb2-p185(HER2) and induces Rac1 and Ras signaling during ovarian tumor cell migration and growth. J Biol Chem. 2001:276(52):48679-92.

61. Bourguignon LY, Singleton PA, Zhu H, Diedrich F. Hyaluronan-mediated CD44 interaction with RhoGEF and Rho kinase promotes Grb2-associated binder-1 phosphorylation and phosphatidylinositol 3-kinase signaling leading to cytokine (macrophage-colony stimulating factor) production and breast tumor progression. J Biol Chem. 2003;278(32):29420-34.

62. Baccelli I, Schneeweiss A, Riethdorf S, Stenzinger A, Schillert A, Vogel V, Klein C, Saini M, Bauerle T, Wallwiener M, et al. Identification of a population of blood circulating tumor cells from breast cancer patients that initiates metastasis in a xenograft assay. Nat Biotechnol. 2013;31(6):539-44.

63. Aktas B, Tewes M, Fehm T, Hauch S, Kimmig R, Kasimir-Bauer S. Stem cell and epithelial-mesenchymal transition markers are frequently overexpressed in circulating tumor cells of metastatic breast cancer patients. Breast Cancer Res. 2009:11(4):R46.

64. Theodoropoulos PA, Polioudaki H, Agelaki S, Kallergi G, Saridaki Z, Mavroudis D, Georgoulias V. Circulating tumor cells with a putative stem cell phenotype in peripheral blood of patients with breast cancer. Cancer Lett. 2010;288(1):99-106.

65. Tsutsui S, Yasuda K, Suzuki K, Tahara K, Higashi H, Era S. Macrophage infiltration and its prognostic implications in breast cancer: the relationship with VEGF expression and microvessel density. Oncol Rep. 2005;14(2):425-31.

66. Leek RD, Landers RJ, Harris AL, Lewis CE. Necrosis correlates with high vascular density and focal macrophage infiltration in invasive carcinoma of the breast. Br J Cancer. 1999;79(5-6):991-5.

\section{Submit your next manuscript to BioMed Central and we will help you at every step:}

- We accept pre-submission inquiries

- Our selector tool helps you to find the most relevant journal

- We provide round the clock customer support

- Convenient online submission

- Thorough peer review

- Inclusion in PubMed and all major indexing services

- Maximum visibility for your research

Submit your manuscript at www.biomedcentral.com/submit 